Teologia i Moralność, Volumen 15(2020), numer 1(27)

doi: 10.14746/tim.2020.27.1.15

ORCID: 0000-0002-1906-4915

\author{
MAGDALENA BIOLIK-MOROŃ
}

University of Silesia in Katowice

Faculty of Theology

\title{
Is there any possibility to convert personalism to practice of psychological research? A case of quality of sexual relationship in marriage
}

\section{Introduction}

Sexuality is an integral part of human nature. Nowadays, we all are witnessing substantial changes in approach to sexuality, which become a serious challenge for moral theology. Sexual relations are, undoubtedly, an important area of living in marriage. A sexual act is a display of closeness and love of the spouses. As John Paul II wrote in the Familiaris consortio, a sexual act is an expression of the unity of the spouses and their strengthening (FC 28). In the contemporary world, the vision of Catholic Church's concerning human sexuality meets constant criticism; it is considered detached from reality and inaccessible. But love is really human (HV 9). At the same time, it can be seen that sexuality lost its beauty and was detached, first from belonging only to marriage and, second, from relationships in general. One may recognize these changes in research on human sexuality.

Contemporary research on human sexuality are strongly focused on the individuality. The sexuality is, therefore, studied from the perspective of an individual rather than from the perspective of a relationship. The examples of this pattern can be observed in questionnaires of sexual satisfaction and that will be presented in the following section of this paper. These measures seems to be focused on one's own sexual pleasure and the direct reference to attachment in the romantic dyad is lacking. The present paper is an attempt to complement existing methods of measurement of human sexuality with the personalistic aspect. It includes the following sections. The goal of the first part of the article is 
semantic analysis of statements used in the sexual satisfaction questionnaires. This aims to uncover the nature of romantic bond which is referred to in the contemporary inquiry of sexual relationships. Next step of the reasoning will be a summary of the metaphysical analysis of love by Karol Wojtyła and theology of the body. In the following section, the author's method to measure sexuality including the personalistic approach is presented. The results obtained in the study with the use of the scale will be presented. The last part will identify the aspects that need further elaboration and the critique of the method.

\section{Individualistic approach in contemporary sexual satisfaction questionnaires}

Sexuality and sensuality are two of the most significant factors of the marital satisfaction both for men and women (Lawrence and colleagues 2008). In psychological research the perception of sexual satisfaction within marriage usually focuses on individual experiences of each spouse rather than on their mutual relationship. The analysis of the content of currently used questionnaires of sexual satisfaction demonstrated that they referred to: (a) individual level of contentment (e.g. „I feel content with the way my present sex life is.” in The Sexual Satisfaction Scale for Women, SSS-W [Meston, Trapnell 2005]; „Sex is a source of pleasure for me” in The Sexual Satisfaction Questionnaire, SSQ [Nomejko, Dolińska-Zygmunt 2014]); (b) frequency of various sexual activities between spouses [,I feel content with how often I presently have sexual intimacy (kissing, intercourse, etc.] in my life." in SSS-W); (c) lack of problems in sexual interactions (e.g. „I don't have any important problems or concerns with sex (arousal, orgasm, frequency, compatibility, communication, etc.)." in SSS-W; "I do not have any problems in my sexual life" in SSQ); (d) so-called sexual compatability (,I often feel that my partner and I are not sexually compatible enough." in SSS-W); (e) the sense of being competent or concerns about being competent in sexual area (,I find myself a poor sexual partner" in SSQ); (f) concerns about partner's reactions to one's difficulties in sexual life ("I feel as I've disappointed my partner by having sexual difficulties." in SSS-W); and only rarely includes some items concerning treating a partner as a specific, unique person (reversed-scored item: „I often feel my partner isn't sensitive or aware enough about my sexual likes and desires." in SSS-W). According to the content of sexual satisfaction questionnaires, the sexual satisfaction seems to be an individual matter, even within marriage. Moreover, spouses seem to be rather instruments to obtain a desired level of satisfaction for each other than an aim per se. The negative aspects of personalistic norm, states that the person is the kind of good which does not admit of 
use and cannot be treated as an object of use and as such the means to an end. According to this norm, the definition of sexual satisfaction which is present in psychological questionnaires appears impersonal. Moreover, in its positive form the personalistic norm confirms that the person is a good towards which the only proper and adequate attitude is love.

In the light of the personalistic norm a current psychological and sexological notion of sexual satisfaction within marriage looks incomplete. The present article offers an attempt to use a personalistic approach, well established in catholic personalism which mainly appears in works of Karol Wojtyła, in practice of psychological research.

\section{Personalistic approach to love and sexuality in Karol Wojtyla's works and theology of the body}

"Love and responsibility", a key work by Karol Wojtyła, characterized a personalistic dimension of relationships between women and men. Wojtyła showed close links between sexual relationship, love and marriage. He proposed the analysis of love on a metaphysical, psychological and ethical level. Metaphysical analysis of love brings together mutual reference of idividuals toward each other and their common reference toward the value of good. Going through an analysis of love as attraction, love as desire, love as goodwill, sympathy and friendship, the author pursued an analysis of spousal love. Wojtyła stated that bethroted love is the culmination of love in general and finds its full realization in marriage (West 2009). Polish saint, beginning with the Genesis "It is not good for the man to be alone" (Gen 2, 18), showed that the human being realizes oneself most fully in love which is self-giving. Being a gift for the other person constitutes the essence of what Wojtyła described as spousal love (Heal 2008). This type of love should be characteristic for a marital relationship between spouses. Wojtyła stressed that sexual devotion is possible only in the context of spousal love because there is no possibility of mutual sexual devotion without giving oneselve to each other. In other words, sexual devotion in the context of other forms of love includes a constant danger of instrumentalization of the other person. Wojtyła continued his reflection on marital love as John Paul II in the first cycle of Wednesday catechesis "He created them male and female". Theology of the body was continued not only by Wojtyła's students but by many other theologians (among others J. Crosby, C. West, C. Anderson). Wojtyła and the subsequent authors paid much attention to the integral vision of man and therefore the integral vision of love. In his first encyclical, Benedict XVI emphasized that man loves not the soul alone or the body itself but the whole man (DCE 5). Sexuality is therefore a way of showing love that will 
combine all dimensions. Love between a woman and a man needs time to grow up. It is not just a feeling. The ideal of love is spousal love, which is mature, not focused on oneself but on another person and on a common relationship.

Love has to go through various stages to become mature and it can become a gift of self. Man learns and shapes such love through all his life (Anderson, Granados 2009). Below will be presented to the various stages of love, which lead to the agape love, spousal, which is a gift of self.

The attraction, an initial stage of love, refers to perceiving the other person as a worthy entity. The attraction is connected mainly with a sphere of senses but also with emotional and volitional spheres. Therefore, we are dealing here with an emotional experience (emotions) which is followed by a decision of will. Wojtyła stressed the importance of the emotional aspect of love. He noted that thanks to this aspect, love has thoroughly human character and produces, in general, the possibility to create relationships between men and women (Wojtyła 1982). However, love can not be based solely on emotions. The volitional dimension, which belongs to the spiritual sphere of man, is also important. Love operates on the level of emotions but also on the spiritual level (volition) (West 2011).

The desire is an aspect of love which is characteristic of the relationship between men and women. As Wojtyła wrote, a human being is either a woman or a man and needs a complementation by the member of the opposite sex (Jan Paweł II 2011). Such need finds its demonstration in sexual desire. This type of love seeks a kind of good which is a man for a woman and a woman for a man. Love as the desire and the desire is not the same. The desire is a feeling of deficit which may be satisfied by an identified good which is a person of the opposite sex. However, it is linked to an instrumental treatment of the second person (as a remedy for satisfying the lack of something). Love as desire is an ,objective need of entity which is directed to the second entity, which is a good and object of aspiration for the first one". This type of love reflects a desire for one's own good. Love as desire is such an aspect of love in which attitudes similar to utilitarian may be reflected (Ślipko 2005).

The dimension of love as benevolence suplemments love as desire. It is a desire of good for the other person. This desire is not selfish. The Polish pope noted that this dimension of love should go together with love as desire (Wojtyła 1982).

It should be pointed out that in the measurement of sexual satisfaction, presented in the previous sections of the paper, the majority of items is referring to love as desire and to love as goodwill. There are very limited references to «higher» levels of love, like those described below.

Wojtyła and other personalists stressed that in love between men and women there are no two self-contained loves but one love, which connects both 
persons to each other similarly to the relationships in Holy Trinity (Wojtyła 1982). Therefore, love in such a relationship should be mutual and similar to the love of Christ and the Church (SC 27). Such love acquires a character of the virtue, creates a communion, and is an evidence of individual's maturity. Mutuality belongs to the nature of love (Semen 2008).

Sympathy is a subjective experience, which is strongly present in the beginning of the romantic relationship. It is based mostly on the emotional experience. Sympathy in itself is good but may also have some drawbacks. The most important drawback can be the subjectivism, which distorts a real image of the beloved person. Other drawback is the lability of emotional experiences which constitute sympathy. Love should not be seen only through the prism of sympathy. Friendship, with a more volitional character, is a complementation of sympathy. Friendship may by summarized by a citation from the Gospel: „Love your neighbour as yourself” (Mt 22,39), which means wanting the good for the second person as for oneself. In the sympathy suplemmented with friendship, both the emotional aspect, which gives warmth and the volitional aspect, which gives stability, are present (Wojtyła 1982).

Wojtyła and theologians of the body stated that spousal love is the culmination of love in general and finds its realization in marriage (West 2009). This type of love should be characteristic for a marital relationship between spouses (Wojtyła 1982; Kopycki 2013). Theologians of the body stress that sexual devotion is possible only in context of such love because there is no possibility to mutual sexual devotion without giving ourselves to each other (Kieniewicz 2018). In other instances, there is constantly present a danger of instrumentalization of the other person.

Moreover, Karol Wojtyła described psychological and ethical dimensions of love. In a psychological dimension, he pointed out an impression, sentiment and emotionality and summarized it in the description of integration of love, based on the combination of psychological experience of love with freedom and truth. For this integration to take place it is necessary to consider an ethical dimension of love.

The focus of this paper is the metaphysical dimension of love because this dimension allows the discrimination of qualitatively different dimensions of love. Psychological and ethical dimensions will not be discussed in detail.

\section{Perception of Spouse as a Person Scale - rationale of a new measure of sexual satisfaction}

Based on Karol Wojtyła's and theologians of the body conception of love (mainly betrothal love), the author tries to create the psychological question- 
naire called "Perception of Spouse as the Person" Scale (which is a subscale of "Perceiving a Marital Act as Celebration of The Sacrament of Marriage" Scale). It is an attempt to translate the theological-philosophical theory into a psychological practice. Karol Wojtyła in his „Love and responsibility” included a psychological dimension of love which demonsrated that Wojtyła recognized psychological dimension of love as important (Later, John Paul II also emphasizes that cooperation between theology and psychology is important (VS).

"Perception of Spouse as the Person" Scale includes two subscales, namely "Subjective Treatment of Spouse” subscale and „Perception of being Personalized by Spouse" subscale.

"Subjective Treatment of Spouse" subscale refers to treating the spouse with respect for his/her dignity, looking upon one's spouse as a person in contrast to treating his/her instrumentally for one's goals fulfillment, a focus on the spouse's well-being even to the higher degree than focussing on one's good. This subscale is based on the catholic personalism. Human being as a person is gifted with dignity and appointed to love (Anderson, Granadson 2009). Within marriage, love accepts a betrothal character which manifests itself in being a full and selfless gift (spouse's good is above one's own prosperity) (Wojtyła 1982; Ślipko 2005). This devotion has both an individual dimension (a devotion of one person to the other) and reciprocal one, inter-individual dimension (communal dimension) (Wojtyła 1982).

"Perception of being Personalized by Spouse" subscale refers to one's perception and sense of being treated by one's spouse as a person. Items included in this subscale beginning with: „I think that my spouse thinks that...”. The rationale for this subscale was an attempt to catch a communal dimension of love and reciprocity of love.

The author proposed the following statements in:

A) Subjective Treatment of Spouse Subscale:

- Sex is for me an experience of my haubsand's/my wife's love. (Love is understood here as a readiness to unselfish devotion to the other human)

- For me, the sexual act (intercourse) is an opportunity to deepen our merital relationhsip.

- I think that sex is an important element of our marital life.

- I think that sex is an opportunity to mutual endowment for me and my spouse. (Endowment means to be concentrated on the well-being of spouse to a higher degree than on one's own good)

- For me, a sexual act is a union with husband/wife.

- I would like my husband/my wife to be my only sexual partner. 
- For me, a sexual act is an opportunity to cherish our marital relationhip.

- I take sexual activeness mainly because of my husband's/wife's sexual needs.

- I care about fulfilling my husband's/my wife's sexual needs.

- Sexual act makes me and my husband/my wife emotionally closer.

- Sex is a rutine action for me. (inversely scored)

- During sexual intercourse I would like to strive for mutual (mine and my spouse's) satisfaction.

- Love (understood as a readiness to unselfish devotion for other human) should be basic for sexual act.

- We talk about our sex with my husband/my wife.

- During a sexual intercourse with my husband/my wife I am trying to create an atmosphere, in which he/she would feel safe.

- I know sexual needs of my husband/my wife.

- During sex I would like to be a gift for my husband/my wife, which means that I would like to concentrate on his/her well-being to a higher degree than on mine.

- Sex is for me nothing more than an act of physical closeness. (inversely scored)

B) „Perception of being Personalized by Spouse Subscale :

- I think that during sexual intercourse my husband/my wife would like to strive for our mutual satisfaction.

- I think that my husband/my wife cares about fulfilling my sexual needs.

- I think that a sexual act is for my husband/my wife an opportunity to deepen our marital relationship.

- I think that my husband/my wife knows my sexual needs.

Scale described above was intended to refer to a relationship between spouses in which they would like to be a gift for each other. An important trait of this scale is the reference only to marriage, because only within marriage a betrothal love could be established in the context of sexuality.

\section{Validation of Perception of Spouse as a Person Scale}

The abovementioned scale was used in the study conducted among participants living in sacramental marriages. The author used additionally a questionnaire measuring sexual satisfaction (Sexual Satisfaction Scale [Davis and colleagues 2006; Sałasińska and colleagues 2012]). 
Three hundred and fifty four individuals participated in the study (200 women and $154 \mathrm{men}$ ). The age of participants ranged from 20 to 69 . The largest group was participants living in marriages lasting more than 20 years $(23 \%)$ and participants living in marriages lasting from 1 to 4 years (also 23\%). The majority of participants $(69 \%)$ belong to various church communities. The vast majority of participants (76\%) was not sexually active before marriage.

Author's Perception of Spouse as the Person Scale and Sexual Satisfaction Scale (measuring physical attractiveness, emotional attractiveness and control) were used in the study. It was hypothesized that perceiving one's spouse in a personalistic manner would be positively correlated with sexual satisfaction. Results of correlational analysis are presented in Table 1.

Table 1. Results of correlation analysis of Perception of Spouse as the Person Scale and Sexual Satisfaction Scale

\begin{tabular}{|c|l|c|c|}
\hline & & $\begin{array}{c}\text { Subjective Treatment } \\
\text { of Spouse }\end{array}$ & $\begin{array}{c}\text { Perception of being } \\
\text { Personalized by Spouse }\end{array}$ \\
\hline 1. & Sexual satisfaction - physical & 0.54 & 0.54 \\
\hline 2. & $\begin{array}{l}\text { Sexual satisfaction - emotio- } \\
\text { nal }\end{array}$ & 0.41 & 0.44 \\
\hline 3. & Sense of control & 0.42 & 0.56 \\
\hline
\end{tabular}

Note. All correlations are significant at $p<0.001$.

Both Subjective Treatment of Spouse and Perception of being Personalized by Spouse were significantly positively correlated with all dimensions of sexual satisfaction. The more spouse treats his of her spouse as a person in sexual relationship, the higher is the sexual satisfaction in marriage. A personalistic approach to spouse, therefore, seems to have an important role for sexual satisfaction.

\section{Conclusions}

The purpose of this paper was to introduce a personalitic approach to psychological analysis of sexual bonds between spouses. The main difficulty was translating the philosophical language of Wojtyła's works into questionnaire entries. Namely, statements used in questionnaire should be easy for readers and should not shallow philosophical precision of Wojtyła simultanously. The present attempt to translate personalistic language to psychological practice in domain of sexuality, i.e. Perception of Spouse as the Person Scale appeared to 
be possible and fruitful as a measure of overlooked dimension of marital sexuality. On the other hand, an identified, personalistic dimension of sexual relationship was positively and substantially related with sexual satisfaction. This result shows that treating one's spouse with a real personalitic reference helps to achieve significantly better relationship than without this type of reference to one's spouse, also in sexual matter.

An abovementioned construction of the scale is not without limitations. Firstly, some items have idealistic character and refer to an ideal state which is approached by people but possibly can not be achieved fully. Participants usually have high tendency to self-idealization which may result in the overstatement of their answers. Participants were homogenic, and they were mainly of practicing Catholics, in majority belonging to church communities, and living according to Christian ethic. Studies conducted in more diversified group may bring interesting results.

Despite abovementioned limitations, the attempt of introduction personalistic approach into measurement of sexual satisfaction of spouses has many advantages. One of them is an opportunity to present Karol Wojtyła's teachings about marital love to wider audience. Additionally, a prepared Scale can be useful not only in studies from the borderline of psychology, theology and philosophy, but also in therapeutic practice (e.g. marital therapy and in pastoral work).

\author{
CZY ISTNIEJE MOŻLIWOŚĆ PRZEŁOŻENIA PERSONALIZMU \\ NA PRAKTYKE BADAŃ PSYCHOLOGICZNYCH? \\ PRZYKŁAD JAKOŚCI RELACJI SEKSUALNEJ W MAŁŻEŃSTWIE
}

\title{
Streszczenie
}

Dzisiaj możemy obserwować kryzys relacji seksualnych między mężczyzną a kobietą. Są one często skoncentrowane na sobie, nietrwałe i oderwane od relacji małżeńskiej. Tą prawidłowość można dostrzec w badaniach nad satysfakcją seksualną, które nie uwzględniają aspektu relacyjnego i są skupione na jednostce. Autor artykułu pragnie zaproponować skalę personalnego postrzegania małżonka, która oparta jest na personalizmie chrześcijańskim i na teologii ciała a ma za zadanie uwzględnić relacyjny aspekt współżycia seksualnego. Jest to propozycja narzędzia, które może wzbogacić badania nad seksualnością człowieka.

Słowa kluczowe: teologia ciała, relacje seksualne, małżeństwo, miłość oblubieńcza, personalizm 
Keywords: theology of the body, sexual relationships, marriage, spousal love, personalism

\section{WYKAZ SKRÓTÓW}

HV - Paweł VI, Encyklika Humanae vitae

FC - Jan Paweł II, Adhortacja Familiaris consortio

VS - Jan Paweł II, Encyklika Veritatis splendor

DCE - Benedykt XVI, Encyklika Deus caritas est

SC - Benedykt XVI, Adhortacja Sacramentum caritatis

\section{BIBLIOGRAPHY}

Anderson C., Granados J. (2009), Wezwani do miłości, tłum. M. Romanek, Warszawa.

Benedykt XVI, (2006) Encyklika Deus caritas est, Kraków.

Benedykt XVI (2007), Sacramentum caritatis, Poznań.

Paweł VI (1999), Encyklika Humanae vitae, Wrocław.

Davis D. and colleagues (2006), "I can't get no satisfaction»: Insecure attachment, inhibited sexual communication, and sexual dissatisfaction, „Personal Relationships”, 13, 465-483.

Hadjadj F. (2013), Kobieta i mężczyzna. O mistyce ciala, tłum. M. Nowak, Poznań.

Jan Paweł II (2011), Mężczyzną i niewiasta stworzyt ich, Lublin.

Jan Paweł II (2000), Adhortacja Familiaris consortio, Wrocław.

Jan Paweł II (1998), Encyklika Veritatis splendor, Wrocław.

Kieniewicz P. (2018), Mał̇̇énski labirynt, Warszawa.

Kopycki P. (2013), Elementarz teologii ciała wedtug Jana Pawła II, Częstochowa.

Lawrence E., Pederson A., Bunde M. and all (2008), Objective Ratings of Relationship Skills across Multiple Domains as Predictors of Marital Satisfaction Trajectories, „Journal of Social and Personal Relationships" 25(3), 445-466.

Meston C., Trapnell P. (2005), Development and Validation of a Five-Factor Sexual Satisfaction and Distress Scale for Women: The Sexual Satisfaction Scale for Women (SSS-W), „The Journal of Medicine", vol. 2, 66-81.

Nomejko A., Dolińska-Zygmunt G. (2014), The Sexual Satisfaction Questionnaire - psychometric properties, „Polish Journal of Applied Psychology”, vol. 12 (3), 105-112.

Sałasińska A., Zawiłowski G., Mateńka W., Lew-Starowicz Z. (2012), Sexuality and selected personality traits in female students who choose to specialize in sexology, „Sexological Review" $8,3 / 31,17-22$.

Semen Y. (2012), Seksualność wedlug Jana Pawła II, thum. Z. Denkowska, J. Urbaniak, Poznań.

Ślipko T. (2005), Zarys etyki szczegółowej. Etyka osobowa, Kraków.

West C. (2008), Teologia ciała dla początkujacych, tłum. M.J. Kaniewscy, Warszawa.

West C. (2011), Eros i agape. Miłość, która daje szczęście, thum. A. Skucińska, Kraków.

Wojtyła K. (1982) Miłość i odpowiedzialność, Lublin.

Magdalena Biolik-Moroń - mgr teologii i mgr psychologii. Studentka studiów teologicznych III stopnia w zakresie teologii moralnej na Wydziale Teologicznym Uniwersytetu Śląskiego w Katowicach. 